\title{
PENGARUH MODEL PEMBELAJARAN KOOPERATIF TIPE TARI BAMBU BERBANTUAN PETA KONSEPTERHADAP KOMPETENSI PENGETAHUAN PKn
}

\author{
Ni Nym. Tri Ayu Sukraningsih ${ }^{1}$, Ni Nym. Ganing ${ }^{2}$, I G. A. Agung Sri Asri ${ }^{3}$ \\ ${ }_{1,2,3}$ Jurusan Pendidikan Guru Sekolah Dasar, FIP \\ Universitas Pendidikan Ganesha \\ Singaraja, Indonesia \\ e-mail: ni.nyoman.tri.ayu@undiksha.ac.id ${ }^{1}$, nyomanganing@gmail.com², \\ igaagungsri.asri@undiksha.ac.id ${ }^{3}$
}

\begin{abstract}
Abstrak
Penelitan ini bertujuan untuk mengetahui perbedaan yang signifikan kompetensi pengetahuan PKn antara kelompok siswa yang dibelajarkan melalui model pembelajaran kooperatif tipe tari bambu berbantuan peta konsep dengan kelompok siswa yang dibelajarkan melalui pembelajaan konvensional siswa kelas IV SD Gugus I Kecamatan Kuta Utara Tahun Pelajaran 2017/2018. Jenis penelitian ini adalah eksperimen semu dengan rancangan nonequivalent control group design. Populasi penelitian ini adalah seluruh siswa kelas IV di Gugus I Kecamatan Kuta Utara Tahun Pelajaran 2017/2018 yang terdiri atas 12 kelas dengan jumlah siswa 438 orang. Sampel penelitian adalah kelas IVB SD No. 4 Dalung sebagai kelompok eksperimen sebanyak 26 orang dan siswa kelas IVA SD No. 5 Dalung sebagai kelompok kontrol sebanyak 26 orang yang diperoleh dengan teknik random sampling. Pengumpulan data menggunakan metode tes dengan bentuk tes objektif pilihan ganda biasa. Data dianalisis menggunakan uji-t (polled varians). Hasil penelitian menunjukkan terdapat perbedaan yang signifikan kompetensi pengetahuan PKn antara kelompok siswa yang dibelajarkan dengan model pembelajaran kooperatif tipe tari bambu berbantuan peta konsep dan kelompok siswa yang dibelajarkan dengan pembelajaan konvensional siswa kelas IV SD Gugus I Kecamatan Kuta Utara Tahun Pelajaran 2017/2018. Sehingga dapat disimpulkan terdapat pengaruh model pembelajaran kooperatif tipe Tari Bambu berbantuan peta konsep terhadap kompetensi pengetahuan PKn siswa kelas IV SD Gugus I Kecamatan Kuta Utara Tahun Pelajaran 2017/2018.
\end{abstract}

Kata kunci: Tari Bambu, Peta Konsep, Kompetensi Pengetahuan Pkn

\section{Abstract}

The aim of this research is to know the significant differences of PKn knowledge competence between a group of students studied by using cooperative learning model type bamboo dancing assisted concept map with a group of students studied by using convensional model of fourth grade students of SD Gugus I Kuta Utara district in 2017/2018. Type of this research is quasi experimental by using non-equivalent control group design. The population of this research were all of fourth grade student of SD Gugus I Kuta Utara district in 2017/208 amounted 438 students of 12 class. The sample of this research were students of IVB SD No. 4 Dalung as an experimental group amounted 26 students and students of IVA SD No. 5 Dalung as a control group amounted 26 students, has got by using the technic of random sampling. The data collected by using the multiple choice method. The data analized by using t-test (polled varians). Result of this research shows that a significant difference of PKn knowledge competence between a group students studied by using cooperative learning model type bamboo dancing assisted concept map with a group students studied by using convensional model of fourth grade students of SD Gugus I Kuta Utara district in 2017/2018. . So it can concludes that there is a significant effect of cooperative learning model type bamboo dancing assisted concept map of PKn knowledge competence of fourth grade students SD Gugus I Kuta Utara district in $2017 / 2018$.

Keywords: Bamboo Dancing, Concept Map, Pkn Knowledge Competence 


\section{Pendahuluan}

Pendidikan di SD merupakan hal yang sangat penting karena sebagai dasar bagi pendidikan selanjutnya. Pendidikan dasar diselenggarakan untuk memberikan dasar pengetahuan, sikap dan keterampilan. Pendidikan dasar inilah yang selanjutnya dikembangkan untuk meningkatkan kualitas diri siswa. Undang-undang Nomor 20 Tahun 2003 tentang Sistem Pendidikan Nasional menyatakan, pendidikan diartikan sebagai usaha sadar dan terencana untuk mewujudkan suasana belajar dan proses pembelajaran agar peserta didik secara aktif mengembangkan potensi dirinya untuk memiliki kekuatan spiritual keagamaan, pengendalian diri, kepribadian, kecerdasan, akhlak mulia, serta keterampilan yang diperlukan dirinya, masyarakat, bangsa, dan negara. Tujuan nasional bangsa Indonesia tercantum dalam alenia keempat yakni "melindungi segenap bangsa Indonesia dan seluruh tumpah darah Indonesia dan untuk memajukan kesejahteraan umum, mencerdaskan kehidupan bangsa, dan ikut melaksanakan ketertiban dunia yang berdasarkan kemerdekaan, perdamaian abadi, dan keadilan sosial" (UUD 1945, 2014:3). Untuk mencapai tujuan tersebut pendidikan harus didesain sedemikian rupa agar siswa mampu untuk berkreasi dalam menemukan pengetahuannya sendiri. Agar dapat mewujudkan tujuan pendidikan nasional maka disusunlah sebuah rencana tertulis yang dikenal dengan kurikulum.

"Kurikulum adalah seperangkat rencana dan pengaturan mengenai tujuan, isi, dan bahan pelajaran serta cara yang digunakan sebagai pedoman penyelenggaraan kegiatan pembelajaran untuk mencapai tujuan pendidikan tertentu" (Permendikbud Nomor 70 Tahun 2013). Selain itu "kurikulum adalah seperangkat rencana dan pengaturan mengenai tujuan, kompetensi dasar, materi standar, dan hasil belajar, serta cara yang digunakan sebagai pedoman penyelenggaraan kegiatan pembelajaran untuk mencapai kompetensi dasar dan tujuan pendidikan" (Mulyasa, 2009:46). Sedangkan menurut Daryanto (2014) kurikulum adalah rancangan pendidikan yang memberi kesempatan kepada peserta didik untuk mengembangkan potensi yang ada pada dirinya untuk memiliki kualitas yang diinginkan masyarakat dan bangsanya. Dari pemaparan di atas, dapat disimpulkan bahwa kurikulum adalah suatu rencana yang disusun sebagai pedoman dalam melancarkan kegiatan pembelajaran untuk mencapai tujuan pendidikan tertentu. Pemerintah terus melakukan pembaharuan dan inovasi dalam bidang pendidikan, salah satunya adalah pembaharuan dan inovasi kurikulum. Serentetan rangkaian pembaharuan terhadap kurikulum diantaranya, pada tahun 2004 dirintis Kurikulum Berbasis Kompetensi, kemudian diteruskan dengan kurikulum 2006 (KTSP) dan sekarang telah diterapkan kurikulum 2013.

"Kurikulum 2013 bertujuan untuk mempersiapkan manusia Indonesia agar memiliki kemampuan hidup sebagai pribadi dan warga negara yang beriman, produktif, kreatif, inovatif, dan afektif serta mampu berkontribusi pada kehidupan bermasyarakat, berbangsa, bernegara, dan peradaban dunia" (Kunandar, 2013:16). Kurikulum 2013 memiliki karakteristik diantaranya mengembangkan keseimbangan antara pengembangan sikap spiritual dan sosial, rasa ingin tahu, kreativitas, kerjasama dengan kemampuan intelektual dan psikomotor. Untuk mempersiapkan kehidupan masa kini dan masa depan siswa, kurikulum 2013 mengembangkan pengalaman belajar yang memberikan kesempatan luas bagi peserta didik untuk menguasai kompetensi yang diperlukan bagi kehidupan di masa kini dan masa depan, dan pada waktu bersamaan tetap mengembangkan kemampuan mereka sebagai pewaris budaya bangsa dan orang yang peduli terhadap permasalahan masyarakat dan bangsa masa kini. Di dalam kurikulum 2013, ada beberapa aspek yang dinyatakan dalam kompetensi inti salah satunya adalah kompetensi pengetahuan. Adanya kurikulum, proses pembelajaran menjadi lebih terencana dan teratur.

Menurut Insan (2017) Pembelajaran adalah suatu sistem yang terdiri atas komponenkomponen yang saling berinteraksi. di dalam pembelajaran terdapat interaksi antara peserta didik dan pendidik, melibatkan unsur-unsur yang saling mempengaruhi untuk mencapai tujuan atau kompetensi yang diharapkan. Pembelajaran dalam menggambarkan kegiatan guru mengajar dan siswa sebagai pembelajar dan unsurunsur lain yang saling 
mempengaruhi. Pembelajaran merupakan upaya guru untuk membantu siswa melakukan kegiatan belajar. Dalam proses pembelajaran, guru memiliki peran penting. Guru yang ideal adalah guru yang kreatif dan inovatif. Kreatif dan inovatif dapat diwujudkan dengan penggunaan model pembelajaran yang dapat menciptakan suasana kelas yang menyenangkan bagi siswa selama proses pembelajaran. Terciptanya suasana kelas yang menyenangkan maka siswa menjadi lebih aktif dalam proses pembelajaran. Proses pembelajaran tersebut harus diterapkan pada semua mata pelajaran termasuk PKn. "PKn memegang peranan yang sangat strategis dalam mempersiapkan dan membina warga negara dengan kualitas" (Winataputra, dkk., 2006). Sedangkan Susanto (2013:233) menyatakan,

Selain itu, perlunya pendidikan kewarganegaraan diajarkan di sekolah dasar ialah agar siswa sejak dini dapat memahami dan mampu melaksanakan hak-hak dan kewajibannya untuk menjadi warga negara Indonesia yang cerdas, terampil dan berkarakter yang diamanatkan oleh Pancasila dan UUD 1945, dan memahami nilai-nilai kedisiplinan, kejujuran, serta sikap yang baik terhadap sesamanya, lawan jenisnya, maupun terhadap orang yang lebih tua.

Berdasarkan hasil observasi di lapangan yang dilakukan pada tanggal 9 Januari 2018 dengan guru wali kelas IV di masing-masing SD Gugus 1 Kecamatan Kuta Utara, pembelajaran yang berlangsung saat ini terkadang menerapkan pembelajaran konvensional maka dari itu perlunya kegiatan pembelajaran agar siswa dilibatkan secara aktif untuk berpikir, berinteraksi, berbuat, mencoba, menemukan konsep baru, atau menghasilkan suatu karya. Selain itu, perlu diterapkan proses pembelajaran yang dapat membantu siswa memperoleh pengetahuan secara bermakna. Guru sudah menerapkan beberapa model pembelajaran di SD sehingga perlu diterapkannya juga model pembelajaran kooperatif tipe Tari Bambu. Menurut Yuniari (2017) Model tari bambu memberikan kesempatan kepada siswa untuk berbagi informasi sehingga dapat membangun konsep (pemahaman) pada saat yang bersamaan dengan pasangan yang berbeda secara teratur. Menurut Desmawati (2014) Tari Bambu merupakan salah satu teknik dari model pembelajaran kooperatif. Teknik ini diberi nama Tari Bambu, karena siswa berjajar dan saling berhadapan dengan model yang mirip seperti dua potong bambu yang digunakan dalam Tari Bambu Filipina yang juga populer di beberapa daerah di Indonesia. Dalam kegiatan belajar mengajar dengan teknik ini, siswa saling berbagi informasi pada saat yang bersamaan. Bahan pelajaran yang paling cocok digunakan dengan teknik ini adalah bahan yang membutuhkan pertukaran pengalaman, pikiran dan informasi antar siswa. Menurut Rizqa (2017) model pembelajaran tari bambu merupakan model pembelajaran yang memberikan kesempatan pada siswa dengan siswa lainnya atau pasangannya dalam berbagi informasi, bertukar pengalaman, sehingga melatih anak dalam berkomunikasi, model pembelajaran tari bambu dapat di gunakan untuk semua mata pelajaran dan pada semua tingkatan usia anak didik. Menurut Harianto (2018) Model pembelajaran Bamboo Dancing atau tari bambu merupakan pembelajaran yang memberikan kesempatan siswa untuk saling berbagi informasi pada saat yang bersamaan dengan pasangan yang berbeda dalam waktu singkat secara teratur strategi ini tepat untuk materi yang membutuhkan pertukaran pengalaman pikiran dan informasi antarsiswa. Meskipun namanya tari bambu, tetapi tidak menggunakan bambu. Siswa yang berjajarlah yang diibaratkan sebagai bambu. Model Pembelajaran Tari Bambu merupakan strategi kooperatif yang dikembangkan oleh Anita Lie (2002). Dinamakan Tari Bambu karena siswa berjajar dan saling berhadapan dengan model yang mirip seperti dua potong bambu. Huda (2013:249) menyatakan, dinamakan Tari Bambu karena siswa berjajar dan saling berhadapan dengan model yang mirip seperti dua potong bambu yang digunakan dalam Tari Bambu Filipina yang juga populer di beberapa daerah di Indonesia. Keunggulan menerapkan model ini yaitu adanya struktur yang jelas dan memungkinkan siswa untuk saling berbagi informasi dengan singkat dan teratur serta memberikan kesempatan pada siswa untuk mengolah informasi dan meningkatkan keterampilan komunikasi. Strategi ini memungkinkan siswa saling berbagi informasi pada waktu yang bersamaan. Keunggulan menerapkan model ini yaitu adanya 
struktur yang jelas dan memungkinkan siswa untuk saling berbagi informasi dengan singkat dan teratur serta memberikan kesempatan pada siswa untuk mengolah informasi dan meningkatkan keterampilan komunikasi. Kegiatan saling bertukar pikiran ini dimaksudkan untuk mengaktifkan struktur kognitif yang dimiliki peserta didik agar lebih siap menghadapi pelajaran yang baru (Asmani, 2016).

Dalam pembelajaran di kelas terkadang siswa lebih dituntut untuk menghafal tanpa adanya pembelajaran bermakna. Pembelajaran perlu lebih menekankan pentingnya belajar konsep bagi siswa dan memiliki sekian banyak konsep-konsep yang akan diajarkan kepada siswa. "Dengan menguasai konsep, dimungkinkan untuk memperoleh pengetahuan yang tidak terbatas" (Tabany, 2014:185). Pada pembelajaran dapat menggunakan peta dalam merumuskan konsep-konsep tersebut yang disebut dengan peta konsep. Peta konsep adalah suatu ilustrasi grafis konkret yang mengindikasikan bagaimana suatu konsep tunggal dihubungkan ke konsep lain pada kategori yang sama (Tabany, 2014). "Peta konsep digunakan untuk mengomunikasikan idea-idea dan relasi-relasi yang kompleks dan/atau membuat struktur berpikir peserta didik menjadi lebih sederhana, sehingga mendorong belajar menjadi lebih bermakna" (Yusuf, 2015:289). Berdasarkan pendapat dari kedua para ahli tersebut, dapat disimpulkan bahwa peta konsep merupakan suatu konsep ilustrasi grafis yang dihubungkan ke konsep lain agar membuat struktur berpikir peserta didik menjadi lebih sederhana dan pembelajaran pun akan lebih bermakna. Penelitian ini didukung oleh penelitian (a) Yuniari (2017) yang menyatakan bahwa terdapat perbedaan hasil belajar IPS antara siswa yang dibelajarkan dengan model pembelajaran Bamboo Dancing dengan siswa yang dibelajarkan dengan model konvensional; (b) Arifin (2012) yang menyatakan bahwa penerapan model pembelajaran kooperatif tipe Tari Bambu dapat berpengaruh terhadap hasil belajar siswa; (c) Yogidibrata (2015) yang menyatakan bahwa penerapan model pembelajaran Bamboo Dancing dapat meningkatkan perkembangan bahasa lisan anak.

\section{Metode}

Penelitian ini dilaksanakan di Gugus I Kecamatan Kuta Utara Tahun Pelajaran 2017/2018. Adapun waktu penelitian ini dilaksanakan pada semester genap tahun pelajaran 2017/2018. Penelitian dimulai dari bulan Desember 2017 sampai dengan bulan Mei 2018. Pelaksanaan penelitian pada masing-masing sampel penelitian pada bulan Maret sampai bulan Mei 2018, perlakukan diberikan sebanyak 6 kali di kelompok eksperimen. Jumlah perlakuan yang diberikan telah disesuaikan dengan jam pelajaran terkait materi dalam penelitian ini yang telah diatur dalam kurikulum dan silabus. Jenis penelitian yang dilakukan dalam penelitian ini adalah penelitian kuantitatif dengan desain eksperimen yaitu desain quasi eksperiment (Eksperimen Semu). Bentuk desain eksperimen yang digunakan adalah Nonequivalent Control Group Design. Rancangan penelitian disajikan pada Gambar 1.

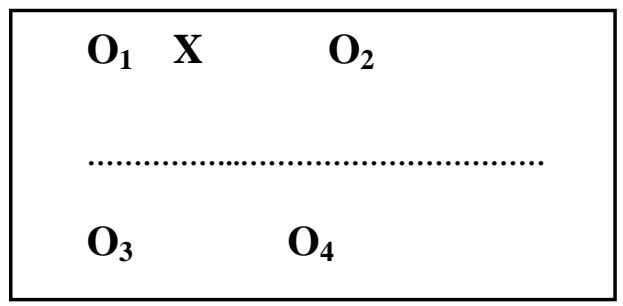

\section{Gambar 1. Rancangan Penelitian Nonequivalent Control Group Design}

Desain ini melibatkan 2 kelas yakni kelas yang mendapatkan perlakuan khusus dengan penerapan Model Pembelajaran Kooperatif Tipe Tari Bambu Berbantuan Peta Konsep sebagai kelas eksperimen, dan kelas yang menggunakan pembelajaran Konvensional sebagai kelas kontrol. Rancangan eksperimen semu Nonequivalent Control Group Design diformulasikan sebagai berikut. 
Pretest diberikan untuk kelompok kontrol dan kelompok eksperimen. Setelah itu peneliti memberikan perlakuan, yaitu dengan memberikan model pembelajaran kooperatif tipe Tari Bambu berbantuan Peta Konsep kepada kelompok eksperimen dan memberikan model pembelajaran konvensional kepada kelompok kontrol. Setelah diberikan perlakuan, dilakukan posttest untuk mengetahui kompetensi pengetahuan PKn.

"Populasi merupakan keseluruhan dari objek, orang, peristiwa, atau sejenisnya yang menjadi perhatian dan kajian dalam penelitian" (Setyosari, 2013:221). "Populasi adalah wilayah generalisasi yang terdiri atas: objek/subjek yang mempunyai kualitas dan karakteristik tertentu yang ditetapkan oleh peneliti untuk dipelajari dan kemudian ditarik kesimpulannya" (Sugiyono, 2016:117). "Populasi adalah keseluruhan objek dalam suatu penelitian" Agung (2014:69). Jadi dapat disimpulkan pengertian populasi adalah sekelompok orang yang mempunyai karakteristik tertentu yang ingin diteliti untuk dipelajari dan kemudian ditarik kesimpulannya. Populasi dari penelitian ini adalah seluruh siswa kelas IV (empat) SD Gugus I Kecamatan Kuta Utara Tahun Pelajaran 2017/2018. Jumlah populasi dari penelitian ini adalah 438 orang.

Pada penelitian ini sampel yang digunakan untuk penelitian adalah bagian dari populasi penelitian. "Sampel merupakan sejumlah kelompok kecil yang mewakili populasi untuk dijadikan sebagai objek penelitian" (Setyosari, 2013:221). "Sampel adalah bagian dari jumlah dan karakteristik yang dimiliki oleh populasi tersebut" (Sugiyono, 2016:118). "Sampel ialah sebagian dari populasi yang dimbil, yang dianggap mewakili seluruh populasi dan diambil dengan menggunakan teknik tertentu" (Agung, 2014:69). Jadi dapat disimpulkan bahwa sampel adalah sejumlah kelompok kecil yang mewakili suatu populasi untuk dijadikan objek penelitian yang secara nyata diteliti dengan menggunakan teknik tertentu. Penggunaan sampel bertujuan untuk menghemat waktu, tenaga, dan biaya dalam melakukan penelitian.

Dalam penelitian ini sampel terdiri atas dua kelas, yaitu satu kelas eksperimen dan satu kelas kontrol. Teknik yang digunakan untuk mengambil sampel dari populasi disebut teknik sampling. Teknik pengambilan sampel pada penelitian ini adalah Random Sampling yang dirandom kelasnya, sehingga setiap kelas mendapatkan peluang yang sama untuk menjadi sampel penelitian.Pemilihan sampel penelitian ini tidak dilakukannya pengacakan individu melainkan hanya pengacakan kelas. Karena tidak bisa mengubah kelas yang telah terbentuk sebelumnya. Kelas dipilih sebagaimana telah terbentuk tanpa campur tangan peneliti dan tidak dilakukannya pengacakan individu, kemungkinan pengaruh-pengaruh dari keadaan siswa mengetahui dirinya dilibatkan dalam eksperimen dapat dikurangi sehingga penelitian ini benar-benar menggambarkan pengaruh perlakuan yang diberikan.

Cara pengundian kelompok sampel dilakukan dengan menulis masing-masing nama kelas IV di seluruh SD populasi pada kertas kemudian digulung. Gulungan tersebut dimasukkan ke dalam sebuah kotak kemudian dikocok. Setelah itu, peneliti mengambil satu gulungan kertas dan mengambil satu gulungan kertas lain tanpa memasukkan kembali gulungan kertas sebelumnya. Nama-nama kelas pada kedua gulungan kertas tersebut merupakan sampel penelitian. Selanjutnya kelas-kelas yang menjadi sampel penelitian tersebut diberikan pretest. Skor dari hasil pretest kelas-kelas tersebut kemudian dianalisis menggunakan uji $t$ untuk penyetaraan kelas. Kemudian peneliti mengadakan pengundian lagi dari dua sampel yang diperoleh untuk menentukan kelompok eksperimen dan kelompok control sehingga dapat ditetapkan kelas IV B SD No. 4 Dalung sebagai kelas eksperimen dan kelas IV A SD No. 5 Dalung sebagai kelas kontrol.

"Variabel adalah segala sesuatu yang akan menjadi objek pengamatan dalam penelitian dan jika diukur memiliki variasi" (Setyosari, 2013:162). Penelitian ini menyelidiki pengaruh variabel bebas yakni Model Pembelajaran Kooperatif tipe Tari Bambu berbantuan Peta Konsep terdahap variabel bebas yakni kompetensi pengetahuan PKn siswa. Data yang diperlukan adalah data tentang Kompetensi Pengetahuan PKn siswa kelas IV SD Gugus I Kecamatan Kuta Utara. Untuk mengumpulkan data Kompetensi Pengetahuan PKn tersebut digunakan metode tes. 


\section{Hasil dan Pembahasan}

Data pada penelitian ini diklasifikasikan menjadi dua yaitu, (1) Kompetensi Pengetahuan Pengetahuan PKn siswa kelas IV yang dibelajarkan dengan Model Pembelajaran Kooperatif Tipe Tari Bambu Berbantuan Peta Konsep, (2) Kompetensi pengetahuan PKn siswa kelas IV yang dibelajarkan dengan pembelajaran konvensional. Deskripsi data kompetensi pengetahuan PKn siswa melalui tabel frekuensi meliputi rerata (mean) dan varians. Berdasarkan perhitungan, kompetensi pengetahuan PKn kelompok siswa yang dibelajarkan dengan Model Pembelajaran Kooperatif Tipe Tari Bambu berbantuan Peta Konsep diperoleh rata-rata yaitu 84,73. Rata-rata kompetensi pengetahuan PKn siswa kelompok eksperimen kemudian dikonversikan pada tabel pengkategorian PAN skala lima, sehingga dapat diketahui kompetensi pengetahuan PKn siswa kelas IV B SD No. 4 Dalung berada pada kategori cukup/sedang. Sedangkan kompetensi pengetahuan PKn kelompok siswa yang dibelajarkan dengan pembelajaran konvensional diperoleh rata-rata yaitu 77,5. Rata-rata kompetensi pengetahuan PKn siswa kelompok kontrol kemudian dikonversikan pada tabel pengkategorian PAN skala lima, sehingga dapat diketahui kompetensi pengetahuan PKn siswa kelas IV A SD No. 5 Dalung berada pada kategori cukup/sedang.

Uji prasyarat dilakukan terlebih dahulu sebelum uji hipotesis menggunakan uji-t. Uji prasyarat tersebut meliputi uji normalitas dan uji homogenitas varians. Uji normalitas dilakukan untuk mengetahui sebaran frekuensi skor, untuk menguji data kompetensi pengetahuan PKn kelompok eksperimen dan kontrol adalah rumus Chi Kuadrat. Kriteria pengujian pada uji normalitas adalah jika $X^{2}$ hitung $<X^{2}$ tabel maka sebaran data kedua kelompok berdistribusi normal.

Berdasarkan hasil uji normalitas kelompok eksperimen, diperoleh Chi Kuadrat hitung $\left(X^{2}\right.$ hitung $\left.=3,72\right)$ kemudian nilai tersebut dibandingkan dengan Chi Kuadrat tabel dengan taraf signifikan $5 \%$ dk $5\left(X^{2}\right.$ tabel= 11,07$)$. Hal ini menunjukkan bahwa $X^{2}$ hitung $<X^{2}$ tabel berarti data kompetensi pengetahuan PKn kelompok eksperimen berdistribusi normal. Berdasarkan hasil uji normalitas kelompok kontrol, diperoleh Chi Kuadrat hitung $\left(X^{2}\right.$ hitung = $4,16)$ kemudian nilai tersebut dibandingkan dengan Chi Kuadrat tabel $\left(X^{2}\right.$ tabel $\left.=11,07\right)$. Hal ini menunjukkan bahwa $X^{2}$ hitung $<X^{2}$ tabel berarti data kompetensi pengetahuan PKn kelompok kontrol berdistribusi normal. Uji homogenitas varians dilakukan terhadap data kompetensi pengetahuan PKn antara kelompok eksperimen dan kelompok kontrol. Pengujian homogenitas varian menggunakan uji $F$ pada taraf signifikansi $5 \%(\alpha=0,05)$.

Dari hasil perhitungan diperoleh $\mathrm{F}_{\text {hit }}=1,16$ sedangkan untuk taraf signifikan $5 \% \mathrm{~F}$ tabel dengan $\mathrm{db}(25,25)$ adalah 1,96. Ini Berarti Fhit $<$ Ftabel, 1,16<1,96 maka data memiliki varians yang homogen. Berdasarkan hasil uji prasyarat yang terdiri dari uji normalitas dan uji homogenitas varians, disimpulkan bahwa data kedua kelompok sampel ialah berdistribusi normal dan memiliki varians yang homogen. Berdasarkan hasil uji normalitas dan homogenitas dapat diketahui bahwa data yang diperoleh dari kelompok eksperimen dan kelompok kontrol berdistribusi normal dan memiliki varians yang homogen. Karena data yang diperoleh telah memenuhi semua prasyarat, uji hipotesis dilakukan dengan menggunakan analisis uji-t. Hipotesis yang diuji dalam penelitian ini adalah hipotesis nol $\left(\mathrm{H}_{\mathrm{o}}\right)$ yang menyatakan bahwa tidak terdapat perbedaan yang siginifikan kompetensi pengetahuan PKn siswa yang dibelajarkan melalui model pembelajaran kooperatif tipe Tari Bambu berbantuan Peta Konsep dengan kelompok siswa yang dibelajarkan melalui pembelajaran konvensional pada siswa kelas IV SD Gugus I Kecamatan Kuta Utara Tahun Pelajaran 2017/2018.Adapun hasil analisis uji t disajikan pada Tabel 1.

Tabel 1. Hasil Analisis Uji T

\begin{tabular}{cccccccc}
\hline No & Sampel & $\mathbf{N}$ & $\mathbf{d k}$ & $\overline{\boldsymbol{X}}$ & $\mathbf{s}^{2}$ & $\boldsymbol{t}_{\text {hitung }}$ & $\boldsymbol{t}_{\text {tabel }}$ \\
\hline 1 & KelompokEksperimen & 26 & 50 & 84,73 & 38,42 & 6,206 & 2,000 \\
\hline
\end{tabular}




2 KelompokKontrol $\quad 26 \quad 77,5 \quad 32,96$

Dengan $\mathrm{db}=\mathrm{n}_{1}+\mathrm{n}_{2}-2$ dan taraf signifikansi $5 \%(\alpha=0,05)$, apabila $t_{\text {hitung }} \leq t_{\text {tabel, }}$, maka $\mathrm{H}_{\mathrm{o}}$ diterima (gagal ditolak) dan $\mathrm{H}_{\mathrm{a}}$ ditolak. Hasil analisis uji $\mathrm{t}$ diperoleh $\mathrm{t}_{\text {hitung }}=6,206$. Harga tersebut kemudian dibandingkan dengan harga $t_{\text {tabel }}$ dengan $\mathrm{dk}=26+26-2=50$ dan taraf signifikansi $5 \%$ sehingga diperoleh harga $t_{\text {tabel }}=2,000$, karena $t_{\text {hitung }}>t_{\text {tabel }} t_{\text {hitung }}=6,206>t_{\text {tabel }}$ $(\alpha=0,05)=2,000$ maka Ho ditolak atau Ha diterima. Hal ini berarti terdapat perbedaan yang signifikan kompetensi pengetahuan PKn antara kelompok siswa yang dibelajarkan melalui Model Pembelajaran KooperatifTipe Tari Bambu Berbantuan Peta Konsep dengan kelompok siswa yang dibelajarkan melalui pembelajaran konvensional siswa kelas IV SD Gugus I Kecamatan Kuta Utara tahun pelajaran 2017/2018. Perolehan data kompetensi pengetahuan PKn pada kedua kelompok dapat diketahui bahwa kedua kelompok yang awalnya memiliki kemampuan setara, lalu setelah diberikan perlakuan yang berbeda, perolehan data kompetensi pengetahuan PKn mengalami perbedaan. kompetensi pengetahuan PKn siswa pada kelompok eksperimen lebih baik apabila dibandingkan dengan kompetensi pengetahuan PKn siswa pada kelompok kontrol. Hal ini disebabkan oleh pembelajaran yang diterapkan pada kelompok eksperimen memiliki keunggulan. Perbedaan yang signifikan kompetensi pengetahuan $\mathrm{PKn}$ antara kelompok eksperimen dengan kelompok kontrol karena perbedaan pemberian perlakuanyang diberikan saat pembelajaran. Kelompok eksperimen diberikan pembelajaran kooperatiftipe tari bambu berbantuan peta konsepmemiliki nilai rerata yang lebih tinggi dibandingkan dengan kelompok kontrol yang diterapkan pembelajaran konvensional. Pembelajaran KooperatifTipe Tari Bambu dipadukan dengan peta konsep akan membuat siswa lebih bersemangat dalam proses pembelajaran. Hal itu karena pembelajaran kooperatiftipe tari bambu berbantuan peta konsepmenekankan kepada siswa untuk mengaktifkan struktur kognitif siswa dan dapat saling berbagi informasi bersama-sama dengan pasangan yang berbeda dalam waktu singkat secara teratur dalam pelaksanaan pembelajaran. Pembelajaran akan menjadi lebih menyenangkan karena adanya interaksi dalam kelas dan pembelajaran menjadi bermakna.

Penelitian ini diperkuat oleh beberapa penelitian yang relevan, di antaranya yakni penelitian yang dilakukan oleh peneliti: Yuniari (2017) menyimpulkan bahwa pengaruh model bamboo dancing berbantuan lingkungan sekitar lebih unggul dengan model konvensional untuk pencapaian hasil belajar IPS siswa, dan penelitian lainnya oleh Yogidibrata (2015) menyimpulkan bahwa dengan diterapkannya model pembelajaran Bamboo Dancing terjadinya peningkatan rata-rata hasil belajar berdasarkan data perkembangan bahasa lisan anak, serta peneliti Lestari (2017) mengadakan penelitian melalui penerapan model Tari Bambu dengan hasil analisis data yang menunjukkan bahwa terjadinya peningkatan rata-rata hasil belajar siswa.

\section{Simpulan dan Saran}

Berdasarkan penelitian yang telah dilakukan maka dapat ditarik simpulan yaitu (1) Kompetensi pengetahuan PKn kelompok eksperimen yang dibelajarkan melalui model pembelajaran kooperatif tipe Tari Bambu berbantuan Peta Konsep pada siswa kelas IV SD Gugus I Kecamatan Kuta Utara tahun pelajaran 2017/2018 diperoleh skor rata-rata $\bar{X}=$ 84,73 yang dikonversikan pada tabel PAN skala lima, sehingga dapat diketahui kompetensi pengetahuan PKn siswa kelompok eksperimen berada kategori cukup/sedang, (2) Kompetensi pengetahuan PKn kelompok kontrol yang dibelajarkan melalui pembelajaran konvensional pada siswa kelas IV SD Gugus I Kecamatan Kuta Utara tahun pelajaran $2017 / 2018$ diperoleh skor rata-rata $\bar{X}=77,5$ yang dikonversikan pada tabel PAN skala lima, sehingga dapat diketahui kompetensi pengetahuan PKn siswa kelompok kontrol berada kategori cukup/sedang, (3) Berdasarkan hasil analisis dengan menggunakan uji-t diperoleh $t_{\text {hitung }}=6,206$ dan dengan taraf signifikan $5 \% \mathrm{dk}=50$ diperoleh $\mathrm{t}_{\text {tabel }}=2,000$, maka 6,206 lebih besar dari 2,000 ini berarti bahwa terdapat perbedaan yang signifikan kompetensi 
pengetahuan PKn antara siswa kelas IV di SD Gugus I Kecamatan Kuta Utara Tahun Pelajaran 2017/2018 yang mengikuti pembelajaran yang menggunakan Model Pembelajaran Tari Bambu Berbantuan Peta Konsep dan siswa yang mengikuti pembelajaran konvensional. Berdasarkan hasil penelitian terdapat perbedaan nilai rerata kompetensi pengetahuan PKn yang lebih tinggi antara siswa yang mengikuti pembelajaran menggunakan Model Pembelajaran Tari Bambu Berbantuan Peta Konsep dan siswa yang mengikuti pembelajaran konvensional yakni, $(\bar{X}=84,73>\bar{X}=77,5)$. Dengan demikian disimpulkan bahwa terdapat pengaruh Model Pembelajaran Tari Bambu Berbantuan Peta Konsep terhadap kompetensi pengetahuan PKn siswa kelas IV SD Gugus I Kecamatan Kuta Utara Tahun Pelajaran 2017/2018.

Berdasarkan hasil penelitian ini, maka dapat diajukan beberapa saran sebagai tindak lanjut dari penelitian ini. Saran ini diajukan kepada berbagai kalangan sebagai berikut. (1) Guru hendaknya menerapkan Model Pembelajaran Tari Bambu Berbantuan Peta Konsep dalam pembelajaran di waktu-waktu tertentu. (2) Kepala Sekolah disarankan agar dapat menggunakan hasil penelitian ini sebagai pendukung sumber belajar guru dalam meningkatkan kualitas pembelajaran dengan menciptakan pembelajaran yang menyenangkan di sekolah sehingga sekolah mampu menghasilkan siswa yang memiliki output berkualitas. (3) Peneliti lain disarankan agar memanfaatkan hasil penelitian ini sebagai referensi untuk melaksanakan penelitian selanjutnya atau menemukan inovasi kegiatan pembelajaran lainnya yang bermakna bagi siswa.

\section{Daftar Rujukan}

Agung, A. A. G. 2014. Metodologi Penelitian Pendidikan. Malang: Aditya Media Publishing.

Al-Tabany, Trianto Ibnu Badar. 2014. Mendesain Model Pembelajaran Inovatif, Progresif, dan Kontekstual. Jakarta: Prenadamedia Group.

Asmani, Jamal. 2016. Tips Efektif Cooperative Learning. Yogyakarta: DIVA Press.

Desmawati. 2014. Penerapan Model Pembelajaran Kooperatif Tipe Tari Bambu Pada Mata Pelajaran Sejarah. Jurnal Tabularasa PPS Unimed Vol. 11 No.1, Hal. 17-28. Tersedia Pada : https://jurnal.unimed.ac.id/2012/index.php/tabularasa/article/view/3331. (diakses tanggal 23 Januari 2018).

Harianto, dan Ambo Dalle. 2018. Keefektifan Model Pembelajaran Kooperatif Tipe Bamboo Dancing dalam Keterampilan Berbicara Bahasa Jerman Siswa Kelas XI IPA SMA Negeri 7 Bulukumba. Jurnal Pendidikan Bahasa Asing dan Sastra Volume 2 No.1 Hal. 9-14. Tersedia Pada : https://ojs.unm.ac.id/eralingua/article/view/5626. (diakses tanggal 23 Januari 2018).

Huda, Miftahul. 2013. Model-Model Pengajaran dan Pembelajaran. Yogyakarta: Pustaka Pelajar.

Isjoni. 2012. Cooperative Learning. Bandung: Alfabeta.

Kunandar. 2013. Penilaian Autentik (Penilaian Hasil Belajar Peserta Didik Berdasarkan Kurikulum 2013). Jakarta: PT RajaGrafindo Persada.

Lestari, Beni. 2017. "Penerapan Model Tari Bambu (Bamboo Dancing) Dengan Media Kartu Dalam Peningkatan Hasil Belajar Pendidikan Kewarganegaraan Tentang Organisasi Di Kelas V Sekolah Dasar". e-journal PGSD Universitas Sebelas Maret Jurusan PGSD, Volume 5, Nomor 5.1 (hlm. 1-6). Tersedia pada jurnal.fkip.uns.ac.id (diakses tangal 23 Januari 2018). 
Peraturan Menteri Pendidikan Dan Kebudayaan Republik Indonesia Nomor 70 Tahun 2013 tentang Kerangka Dasar Dan Struktur Kurikulum Sekolah Menengah Kejuruan/Madrasah Aliyah Kejuruan. 2013. Jakarta: Departemen Pendidikan dan Kebudayaan.

Rizqa, Auliya. 2017. Pengaruh Model Pembelajaran Tari Bambu didukung Media Visual terhadap Hasil Belajar dalam Menjelaskan Berbagai Energi Alternatif dan Cara Penggunaannya Siswa Kelas IV SDN Banjaran 3 Kota Kediri Semester 2 Tahun Ajaran 2016/2017. Simki-Pedagogia Vol. 01 No. 09 Hal. 1-12. Tersedia Pada : simki.unpkediri.ac.id. (diakses tanggal 23 Januari 2018).

Setyosari, Punaji. 2013. Metode Penelitian Pendidikan \&Pengembangan. Jakarta:Prenamedia Group.

Sugiyono. 2010. Statistik Untuk Penelitian. Bandung: Alfabeta.

Sugiyono. 2011. Metode Penelitian Pendidikan Pendekatan Kuantitatif, Kualitatif, dan R\&D. Bandung: Alfabeta.

Sugiyono. 2016. Metode Penelitian Pendidikan. Bandung: Alfabeta.

Susanto, Ahmad. 2013. Teori Belajar dan Pembelajaran di Sekolah Dasar. Jakarta: Prenadamedia Group.

Undang-Undang Dasar 1945, 2014. Surabaya: Apollo Lestari.

Winataputra, Udin dkk., 2006. Materi dan Pembelajaran PKn SD. Jakarta: Universitas Terbuka.

Yogidibrata, Pramesti. 2015. "Penerapan Model Pembelajaran Bamboo Dancing Berbantuan Media Gambar Untuk Meningkatkan Perkembangan Bahasa Lisan Anak Kelompok B3 TK Widya Santhi Denpasar". e-journal PG-PAUD UNDIKSHA Jurusan PGPAUD, Volume 3, Nomor 1 (hlm. 1-10). Tersedia pada ejournal.undiksha.ac.id (diakses tanggal 23 Januari 2018).

Yuniari, Wayan. 2017. "Pengaruh Model Bamboo Dancing Berbantuan Lingkungan Sekitar Terhadap Hasil Belajar IPS Siswa Kelas V SD". e-journal PGSD UNDIKSHA Jurusan PGSD, Volume 5, Nomor 2 (hlm. 1-12). Tersedia pada ejournal.undiksha.ac.id (diakses tanggal 23 Januari 2018).

Yusuf, A. Muri. 2015. Assesmen dan Evaluasi Pendidikan. Jakarta: Prenadamedia Group. 